\title{
Emuna e pistis: a noção de fé no pensamento de Martin Buber $^{1}$
}

\author{
Emuna and pistis: the notion of faith in Martin Buber's thought
}

Newton Aquiles von Zuben*

\begin{abstract}
Resumo
No paradigma estabelecido pela dualidade de "palavras-princípio" (Grundwort) Eu-Tu e Eu-Isso, a intuição axial do pensamento dialógico de Martin Buber se constitui como pedra angular de sua obra sobre religião: a dupla disposição de um homem-Eu e de Deus-Tu fundada num encontro recíproco. A fé - Glauben - é a resposta do homem a Deus, no encontro no qual Ele se mostra pela Palavra como Tu Eterno na revelação como mistério de Presença. Buber propõe duas maneiras opostas de crer: de um lado, a Emunah, como confiança pessoal ou abandono confiante de um povo, Israel, que se deixa guiar por Deus e, de outro lado, a Pistis, a qual, segundo o apóstolo Paulo, é a adesão individual a um conteúdo de fé, de um credo tido por verdadeiro. Os dois modos de crer, embora haja diversidade nos conteúdos de fé, podem ser apreendidos a partir de experiências vividas: tenho confiança em alguém e reconheço um fato como verdadeiro. Para tais experiências, não se consegue "dar razão" ou justificá-las. O objetivo deste texto é apresentar, de maneira sucinta, o pensamento de Martin Buber sobre essa questão que pode ilustrar o seu entendimento das relações entre o Cristianismo helenista e o Judaísmo.
\end{abstract}

Palavras-chave: Emunah; Pistis; Fé; Martin Buber.

\begin{abstract}
The axial insight from Buber's thought settled a paradigm by the duality of the "guiding- word principle" (Grundwort) I-Thou and I-It that is form as a keystone of his handwork about religion: the duet disposition of a man-I and a God-thou grounded on a mutual encounter. Faith - Glauben - is the man's answering to God, in the encounter which He revels himself by the guiding-word Divine-Thou as Presence of a mistery revealed. Buber suggest two different ways to believe: in one hand, the Emunah, as a personal trust or the abandonment from a people trustful, Israel, which is leaded by God and, on the other hand, the Pistis, which, according to Apostle Paul, it is an individual adherence for a Faith content, that is hold as a truthful creed statement. The two ways of believing, although there is diversity in the faith content, it can be learned from experiences: I have confidence in someone and recognize a fact as true. For those experiences, it is not possible to "give a reason", or to justify them. This paper aims to present, succinctly, Martin Buber's thought about this question that may illustrate his own comprehension about the relation between Hellenistic Christianity and Judaism.
\end{abstract}

Keywords: Emunah; Pistis; Faith; Martin Buber.

Artigo recebido em 26 de agosto de 2016 e aprovado em 28 de março de 2017.

1 Este texto retoma, com modificações, a Comunicação apresentada no 29o Congresso Internacional SOTER, realizado em Belo Horizonte - 2016 .

* Doutor em filosofia (Université Catholique de Louvain, 1970, tese sobre Martin Buber). Atuou na PUC-SP (1971-1974) e Unicamp (1974-2001). É professor titular da Pontifícia Universidade Católica De Campinas. Atua na área de filosofia, com ênfase em ciências da religião, ética, antropologia filosófica, bioética e fenomenologia. País de Origem: Brasil. E-mail: nzuben@puc-campinas.edu.br.

Horizonte, Belo Horizonte, v. 15, n. 45, p. 134-162, jan./mar. 2017 - ISSN 2175-5841 


\section{Introdução}

Martin Buber deixou sua marca na história como o pensador do diálogo e do judaísmo. Sua trajetória intelectual e existencial, assim como a vasta obra em domínios diversos, modelaram-no, de modo peculiar, como eminente personagem do século XX. Desde sua infância, o universo religioso do judaísmo esteve presente: sua família teceu o horizonte cultural e religioso que serviu de base para seus interesses futuros. Após sua formação acadêmica em Viena, seus estudos seriam dedicados ao misticismo alemão medieval, com uma tese doutoral, "Para uma história do problema da individuação: Nicolau de Cusa e Jakob Böhme"2, defendida na Universidade de Viena, em 1903. Na sequência, dedicou-se ao estudo da mística hassídica, com inúmeras obras de compilação sobre relatos da vida das comunidades hassídicas e ensaios de interpretação e análise dessa corrente mística.

Buber apresentou-se como "homem atípico". No entanto, sua vasta produção literária, abrangendo os campos da filosofia, da religião, da educação, da política, da mística, da hermenêutica bíblica, incluindo sua tradução da Bíblia hebraica para o alemão, permite entendê-lo como um pensador da religião. Alguns autores o classificam como um cientista da religião (Religionswissenschaft), outros como filósofo da relação dialógica. Na realidade, deve-se notar a consideração de Buber exposta na obra editada por Schilpp (1967), ao final da obra na parte "Respostas do filósofo":

Nesta obra discute-se diversas vezes se sou filósofo ou teólogo ou algo mais. A questão é posta corretamente, pois dependendo da circunstância devo confrontar-me com regras e lei de um ou outro desses domínios. Não posso, todavia, eu próprio, propor uma resposta a propósito disso. Tanto quanto alcança meu auto-conhecimento, posso dizer que sou um homem atípico. Minha aversão a usual tipologia excessiva, talvez repouse sobre esse fato. (SCHILPP, 1967, p. 289).

$\mathrm{Na}$ realidade, notáveis intérpretes da obra e do pensamento de Buber, atentaram muito bem para sua notável observação "sou um homem atípico".

\footnotetext{
${ }^{2}$ Zur Geschichte des Individuationsproblem: Nicholas von Cuse und Jakob Böhme (BUBER, 1903).
} 
Mesmo assim contribuíram, cada qual de uma perspectiva, e analisaram aspectos diversos do pensamento de Buber, compreendendo que há, apesar da multiplicidade de domínios nos quais ele atuou, uma busca intensa de unidade que percorre cada etapa. Não uma unidade dada, mas ordenada. Essa exigência de unidade que foi sendo construída como a unificação do homem parta poder encontrar o outro como Tu e o Tu eterno. A busca dessa unidade foi o horizonte de “sentido” da obra e pensamento de Martin Buber. Daí a universalidade e a coesão dessa obra. Para tentar suplantar o esfacelamento nefasto da nossa civilização (presente à época do autor e que ainda perdura), Buber abordou a realidade sob as mais diversas perspectivas. Quer se trate da mística cristã e a mística hassídica, do profetismo veterotestamentário, da hermenêutica bíblica, de filosofia, de antropologia, de educação, de política ou sociologia era a mesma preocupação fundamental: como o homem do século XX, depois de tudo por que passou, pode ele ter a esperança de se defrontar novamente da realidade, de tal modo a que possa encontrar um sentido? Um sentido que ele tivesse construído, mas que lhe fosse manifesto permitindo-lhe de, simplesmente ser.

De fato, na volumosa obra editada por Paul Schillp, há autores que se referiram a Buber como filósofo, tais como, Emmanuel Levinas, Maurice Friedmann, Charles Horthshorne, Gabriel Marcel, Philip Wheelwright e Fritz Kaufmann. Outros o trataram como teólogo e hermeneuta bíblico, como Emmil Brunner, Malcolm Diamond, Hans Urs von Balthasar, Nahum Glatzer, Emil Fackemheim. E, ainda outros o consideraram como notável estudioso da mística cristã e judaica, em especial a mística hassídica, como Frank Kaufmann, Greshom Scholem e David Flusser. Jean Whal, filósofo francês, o aproxima das filosofias da existência. Guy Stroumsa, filósofo, especialista em religião comparada alia Buber ao campo da história da religião, mas argumenta que a denominação cientista da religião (Geisteswissenschaftler) seria igualmente apropriada. Maurice Friedman, eminente tradutor para o idioma inglês das obras de Buber e Nathan Rotenstrich, filósofo da Universidade Hebráica de Jerusalem, o consideram um filósofo do diálogo, cuja obra contribui a uma ontologia da vida humana. 
Julgo pertinente, para adequada compreensão da multifacetada obra desse pensador, levar em conta alguns fatores decisivos. Em primeiro lugar, Martin Buber foi um dos mais renomados pensadores e escritores do judaísmo do século XX, cuja obra completa se estende de 1902 até sua morte, em 1965; em segundo lugar, seu campo principal de estudo foi o judaísmo e a mística hassídica, ao lado de inúmeras obras no campo da filosofia, sociologia, educação, política e mística oriental; em terceiro lugar, seus ensaios de hermenêutica e exegese bíblica exerceram especial influência, tanto em autores judeus quanto cristãos, destacando-se, especificamente, sua tradução para o idioma alemão da Bíblia hebraica, sendo, aliás, um dos mais destacados estudiosos judeus das relações entre o judaísmo e o cristianismo. 3 Finalmente, conhecido como o filósofo do diálogo, deve-se destacar a centralidade e a relevância do seu pensamento, na obra filosófico-poética publicada em 1923, Eu e Tu4, considerado por ele próprio como sua mais importante produção. Hans Urs von Balthazar assim se referiu a Buber:

Martin Buber é uma das mentes mais criativas de nossa época. Muitos daqueles que o conheceram por meio de sua notavelmente rica obra literária, e por fascínio de suas palestras ou por encontros pessoais testemunham somente um dos seus aspectos: vêem o homem de sabedoria, o filósofo religioso, o brilhante tradutor da Escritura cujo gênio captou pela primeira vez algo do espírito da antiga linguagem hebraica para o alemão, o infatigável renovador e intérprete do Hassidismo, ou, finalmente o teórico do Judaísmo contemporâneo. (BALTHAZAR, 1967, p.340).

A questão da fé ocupa um lugar proeminente no pensamento e nas obras de Buber consagradas no campo amplo da religião, da hermenêutica bíblica e do sentido e tarefa do judaísmo, no mundo moderno, uma de suas principais preocupações. Basicamente, essa questão da fé encontra-se em três obras: "Moisés"; "A fé dos profetas"; e "Dois tipos de fé. A fé judáica e as fé cristã".5.

\footnotetext{
${ }^{3}$ Como não será desenvolvida essa questão das relações entre judaísmo e cristianismo, sugiro ao leitor os trabalhos de Hans Urs von BALTHAZAR, Martin Buber and Christianity (1967), e de Emil BRUNNER, Judaism and Christianity (1967), ambos indicados nas Referências. E mais, David FLUSSER, Judaism and the Origins of Christianity (2003).

${ }^{4}$ Ich und Du.

${ }^{5}$ Moses (BUBER, 1945), Der Glaube der Propheten (BUBER, 1950) e Zwei Glaubensweise (BUB ER, 1950). Nenhuma delas foi traduzida para o português.
} 
Meu presente estudo se restringirá à obra Dois tipos de fé. Afé judaica e a fé cristã, publicada em Zürich, em 1950. ${ }^{6}$ Note-se, entretanto, que, em Eu e Tu, Buber já desenvolvera reflexões sobre a fé como resposta do homem, no encontro dialógico, à palavra do Tu Eterno. Essa obra de 1923 é o ponto nodal do horizonte de pensamento de Buber, estando presente, a montante e a jusante, de alguma maneira, em toda a sua produção intelectual de caráter filosófico-espiritual.

De início, Buber declara que, com Dois Tipos de Fé, não foi movido por uma intenção apologética. "Será necessário dizer que me encontro a mil léguas de toda tendência apologética?” (BUBER, 2007, p. 33). É essencialmente uma obra de interpretação. O título e o subtítulo explicitam bem: trata-se da dualidade de tipos de fé, a fé judaica e a fé cristã. O argumento central da obra se pauta na definição de dois universos de crença, o judaísmo e o cristianismo.

Destaca-se, ademais, o interesse pela figura de Jesus, o Nazareno pertencente à comunidade judaica, tratado com respeitoso sentimento pessoal do autor, quando declara:

Desde minha juventude, percebi Jesus como meu irmão mais velho. Que a cristandade o tenha considerado e o considere como Deus e Redentor, sempre me pareceu como um fato a ser tomado de modo extremamente sério que devo buscar compreender por ele mesmo e para mim mesmo. [...] Minha relação pessoal de abertura fraterna com Jesus foi aprofundada e purificada, e eu a vejo hoje de um olhar mais intenso e firme que nunca. (BUBER, 2007, p.33).

Pode parecer surpreendente para cristãos e judeus o uso do termo "irmão", pois sugere que Jesus e Buber se relaciona do mesmo modo com Deus, Pai de ambos. Mas, na verdade, Buber rejeita as duas concepções que cristãos e judeus têm de Jesus. Para ele, Jesus é o herdeiro da tradição judaica. Sua intenção é resgatar Jesus para o judaísmo.

Essa obra é uma das concretizações da relevância que Buber atribui ao Novo Testamento. Em suas palavras: "O Novo Testamento é, para mim, desde há

${ }^{6}$ Utilizarei para as referências a tradução francesa Deux types de foi (BUBER, 2007), de mais fácil acesso. 
aproximadamente 50 anos, um dos meus principais objetos de estudo e, penso ser um bom leitor que escuta sem preconceito o que lhe é dito.” (BUBER, 2007, p.33).

É pertinente observar eventos que corroboram esse depoimento de Buber. Interessado, como afirmou, pelo estudo comparado das religiões, em 1933, ele participou de debate com Karl Ludwig Schmidt, teólogo cristão, especialista em exegese neotestamentária, ocorrido na Jüdisches Lehrhaus, na cidade de Stuttgart, sobre as relações entre cristianismo e judaísmo. Mais tarde, já residente em Jerusalém, proferiu nos anos 1942-43 uma série de palestras sobre as origens judaicas do cristianismo, numa escola que abrigava uma pequena sinagoga de judeus alemães. Segundo o testemunho de seu amigo Schalon Ben-Chorin, cientista da religião, jornalista alemão-israelense e grande promotor do diálogo entre cristianismo e judaísmo, teria sido a primeira vez que se promovia, numa sinagoga, um evento dedicado ao comentário do Evangelho, e sobre a "judaicidade" de Jesus (BEN-CHORIN, 1966). Aliás, note-se que Buber manteve contato franco e respeitoso com teólogos cristãos, como Rudolf Bultmann, Albert Schweitzer, Rudolf Otto, Emil Brunner, assim como o católico Romano Guardini. Todos esses teólogos foram citados na introdução de seu livro. Muitos outros, em especial Paul Tillich e Joseph Ratzinger, reconheceram a presença ou a influência de Buber em seus próprios pensamentos e obras. Refere-se, também, a seu amigo Leonhard Ragaz, teólogo reformado, um dos fundadores do socialismo religioso na Suíça.

Reputo relevante tomar conhecimento dessa obra, pelo reconhecimento, de maneira especial, de notáveis teólogos católicos, os quais apresentaram, de modo crítico, análises sobre esse tema da relação entre cristianismo e judaísmo, sublinhando sua contribuição ao estudo da cristologia e das relações e diálogo entre as religiões.

Proponho, neste estudo, seguir por duas etapas: primeira, expor, de modo sucinto, o cenário conceitual dialógico de $E u$ e Tu, em especial, as reflexões sobre a relação com o Tu Eterno, onde encontramos as considerações sobre as características dessa relação e suas reflexões sobre a fé como resposta do homem ao 
apelo - a revelação - do Tu Eterno na relação dialógica. Em seguida, analisar, na obra Dois Tipos de fé, com recorte nos três primeiros capítulos, como Buber argumenta, após definição, o significado da dualidade Emunah e Pistis, respectivamente a fé do judaísmo e a fé do cristianismo. Ver-se-á como ele distingue, opondo-as, a fé messiânica “de” Jesus à fé dogmática “em” Jesus Cristo. A questão é: como se expressa a fé daquele que crê? Nessa segunda etapa, examinarei como se manifesta, segundo Buber, nos textos evangélicos relacionados com passagens do Antigo Testamento, a experiência dos dois tipos de fé.

\section{1 horizonte conceitual da noção de fé: a vida dialógica}

No início de $E u$ e $T u$, Buber usa a estrutura dual pela qual molda suas reflexões. Assim, afirma ele:

O mundo é duplo para o homem, segundo a dualidade de sua atitude. A atitude do homem é dupla de acordo com a dualidade das palavrasprincípio que ele pode proferir.

As palavras-princípio não são vocábulos isolados, mas pares de vocábulos. Uma palavra-princípio é o par EU-TU. A outra é o par EU-ISSO no qual, sem que seja alterada a palavra-princípio, pode-se substituir ISSO por ELE OU ELA.

Deste modo, o EU do homem é também duplo.

Pois, o EU da palavra-princípio EU-TU é diferente daquele da palavraprincípio, EU-ISSO. (BUBER, 2012, p.51).

Pouco antes da publicação dessa obra, ele havia proferido uma série de conferências com o título Religião como presença7, nas quais já tinha introduzido a ideia de encontro dialógico, com aquilo que seria denominado, no ensaio filosófico de 1923, como relação Eu-Tu e relação Eu-Isso. Nessa obra, o autor evidencia uma ontologia da relação. Desse modo, estaria posto o fundamento da vida de diálogo a ser realizado pelo homem no mundo, indicando já a importância da vivência concreta existencial (do "aqui e agora”, o "presente” (Gegenwart). Aí nos mostra a

\footnotetext{
${ }^{7}$ Religion als Gegenwart é o título de uma série de oito conferências que Buber proferiu na Freies Jüdisches Lehrhaus, Escola Livre Judaica. Buber considerava essas conferências como "prolegómenos a uma filosofia da religião". O texto original foi publicado na obra de Rivka Horwitz, Buber's Way to "I and Thou" (1978). An historical analysis and the first publication of Martin Buber's "Religion als Gegenwart".
} 
realidade de relações entre o humano e o Incondicionado, o Tu eterno. "As linhas de todas as relações, se prolongadas, entrecruzam-se no TU eterno. Cada TU individualizado é uma perspectiva para ele. Através de cada TU individualizado a palavra-princípio invoca o TU eterno.” (BUBER, 2012, p. 99).

Como Buber apresenta a noção de fé, na terceira parte dessa obra?

A fé é o encontro dialogal entre Deus e o homem. À invocação do Tu Eterno, o homem responde a esse apelo. Ela não implica nenhuma base noética, pois um conhecimento nos colocaria diante de um Isso, e Deus é justamente o único Tu que, por sua essência, jamais pode se tornar um Isso.

O Tu eterno não pode, por essência, tornar-se um Isso, pois ele não pode reduzir-se a uma medida ou a um limite mesmo que seja a medida do incomensurável, ao limite do ilimitado. Por essência ele não pode ser concebido como uma soma de qualidades elevadas à transcendência. [...]; nós pecamos contra Ele, o Ser, quando dizemos: "Eu creio que Ele é"; Ele é uma metáfora, mas Tu não é uma metáfora.” (BUBER, 2012 p. 123-124).

Buber, quando questionado sobre a frase "Ele é uma metáfora, mas Tu não é uma metáfora”, explicita o seu exato sentido:

Se alguém fala de Deus, transforma-o como algo existente dentre outros existentes, como algo disponível, constituído dessa forma e não de outra. No entanto, falar a Deus nada mais é que tornar-se para Ele mesmo. [...] Nada é exigido senão o tornar-se totalmente. [...] A metáfora não tem mais lugar aqui. (BUBER, 1967, p. 713-714).

O Deus da fé é essencialmente um Tu, e a fé pertence então à dimensão dialogal. Ela é, por natureza e por essência, uma relação que não é baseada em fundamentos, nem resulta desses fundamentos. E mais, a relação dialógica é recíproca e imediata, não carecendo de intermediário algum. É certo que há julgamentos que podem se fazer valer, mas jamais serão discutidos pela fé. Seria mesmo falso querer fazer derivar o evento dialogal da fé de conhecimentos científicos. Na fé, o Eu encontra Deus como pessoa. Isso não nos permite concluir, contudo, que a pessoa de Deus seja sua própria essência. Deus continua, para o 
homem, o "Todo outro”, o mistério insondável. A fé não é uma relação noética de um sujeito cognoscente com um objeto conhecido. É um contacto mútuo, o verdadeiro encontro, na reciprocidade e na totalidade de vida, entre um Eu e um Tu. A fé resulta desse encontro entre o homem e o Tu Eterno.

Toda relação real no mundo realiza-se numa permuta de atualidade e latência, todo TU individual deve transformar-se em crisálida do ISSO para que as asas cresçam novamente. Mas, na verdadeira relação, a latência não é mais que a pausa da atualidade onde o TU permanece presente. O TU eterno é, segundo sua essência, um TU; é nossa natureza que nos obriga a inseri-lo no mundo do ISSO e na linguagem do ISSO. (BUBER, 2012, p.115).

O autor alude igualmente à situação singular do homem, quando em relação com o Tu Eterno, ao afirmar:

Sem dúvida Deus é o "totalmente Outro", Ele é, porém o totalmente mesmo, o totalmente presente. Sem dúvida, ele é o "mysterium tremendum" cuja aparição nos subjuga, mas Ele é também o mistério da evidência que me é mais próximo do que o meu próprio EU. (BUBER, 2012, p. 102).

Segundo Buber, Deus não quer, aliás, que o homem se ocupe dele como de um objeto, mas antes que o homem entre em relação dialógica com Ele. Se o homem se coloca e se instala no mundo do conhecimento e da experimentação, no domínio da filosofia e da teologia, Deus será apreendido como um Deus coisificado ou como um objeto a partir do qual derivam todos os objetos do mundo. O conhecimento científico de Deus se baseia na dualidade sujeito-objeto, mundo do Isso.

Não poderíamos, contudo, negar simplesmente o valor dessa “atividade" reflexiva de desvelamento de Deus. Esse valor repousa na circunstância de que, de um lado, o próprio pensador pode entrar, com a ajuda dessa atividade reflexiva, numa relação dialogal com Deus; de outro lado, os sistemas filosóficos e teológicos são, sem dúvida alguma, guias capazes de indicar o caminho que leva até Deus. Pela vivência da fé, na palavra recíproca do encontro, o significado dialogal do homem pode se realizar. 
Mesmo o fato, próprio ao homem, de ser criatura manifesta também, plenamente, uma resposta a um apelo. Ao criar, Deus chama um Tu à existência, e lhe endereça sua Palavra; por conseguinte, o homem é homem na medida em que é um Tu para Deus. É nesse aspecto que se encontra, para Buber, o significado profundo do Tu inato. Com efeito, o Tu é inato, no homem, como uma capacidade, uma aptidão primitiva de responder à interpelação de uma invocação. $\mathrm{O}$ homem está consciente do apelo do mistério de Deus, e realiza seu ser, sua existência, na medida em que também endereça, numa confiança exclusiva, a palavra-princípio dialogal a Deus. Nesse acontecimento na relação de fé, o homem se encontra presente dialogicamente diante de Deus. Ele não experimenta nada de especial, mas está, simplesmente, presente diante do Tu eterno, presente na sua totalidade. Deus é Presença a quem sempre podemos endereçar o Tu.

Se quisermos comparar a fé com a relação ao "Tu" individualizado, devemos ter em conta duas diferenças básicas. Em primeiro lugar, a relação com o Tu individualizado não depende somente de um Eu, pois aquele que é meu Tu, no mundo, pode estar ausente. É preciso notar ainda que, na vida com os homens, a realização do evento dialogal não depende só de minha liberdade, mas também da liberdade do Tu. Tanto o Eu como seu interlocutor, o seu Tu, podem se recusar a entrar em relação. A relação com Deus é diferente. Deus é o Eu do qual meu Tu surgiu; ele é meu Tu Absoluto, que jamais pode tornar-se um Isso; ao passo que os outros homens, ao desprezarem minha interpelação, podem continuar seres separados. A segunda diferença está no fato de que, no mundo, a relação se completa na reciprocidade de sua realização. Como o Eu se completa em contato com o $\mathrm{Tu}$, em contrapartida, da mesma maneira, o Tu se completa em contato com o Eu. No que diz respeito à relação com Deus, não se pode dizer que Ele se completa, na fé, através do Eu que está em relação com Ele; Ele é sempre o Tu eterno, o Tu Absoluto, e o Eu é criado e se realiza sem cessar. 


\section{Emuna e Pistis}

Uma das características do pensamento de Buber é o uso de estruturas duais, como já observei. Era a sua convicção que em tudo reinava o princípio da dualidade. Em diversas obras, ele utiliza esse modo de apresentar as questões.

Em Dois tipos de fé, retoma procedimento semelhante. Aqui a fé tem seu foco centrado nas relações do homem com Deus, enquanto, em Eu e Tu, as relações se davam em três esferas: com o ser humano, com os seres espirituais e com Deus. Dois tipos de fé foi gestada na década de 1940, período aterrorizante por todos conhecido, o qual poderia ser qualificado, à luz de obra posterior de Buber, como "eclipse de Deus".

Como Buber apresenta a questão? Logo no início da obra, ele afirma:

O tema sobre o qual trato aqui é a dualidade da fé. Duas maneiras de crer, e definitivamente somente duas se defrontam. Embora haja, de fato, vasta diversidade de conteúdos de fé, a fé mesma, nós não a conhecemos senão sob duas formas fundamentais. (BUBER, 2007, p. 29).

O autor acrescenta que é fácil evocar ambas, com base na observação de simples fatos cotidianos. Uma, a partir do seguinte: tenho "confiança" em alguém, mesmo que não possa fundar em razões a confiança nele depositada; e outra, "reconheço" fatos como verdadeiros e, aqui também, sem poder dar razão suficiente. Não poder dar razão não significa alguma deficiência de minha parte, todavia, refere-se à particularidade da relação com aquele em quem deposito confiança ou com aquilo que reconheço como verdadeiro.

A fé, ressalta Buber, é um ato de relação do qual não posso dizer "porquê" ou dar razões, pois é uma relação que, por natureza, não se funda em razões. "O 'porquê' vem sempre posteriormente, mesmo que ele aflore desde os primeiros estágios do processo; com efeito, desde que aparece, ele está assinalado como excedente." (BUBER, 2007, p.29). Não se trata, absolutamente, de "fenômenos irracionais", assinala o autor: 
Minha racionalidade, minha função pensante, racional, não é, com efeito, senão uma parte uma função parcial de meu ser; entretanto, quando de uma maneira ou outra, eu "creio", é meu ser inteiro, a totalidade de meu ser que entra nesse processo, e mesmo ele só se torna possível quando essa relação de fé é uma relação de meu ser na sua totalidade. (BUBER, 2007, p.29).

Há dois tipos de fé. E quem é aquele que crê? Aquele que repousa sua experiência religiosa na relação pessoal com Deus. Pode-se entender que a questão teológica será direcionada à questão existencial, uma vez que os dois tipos de fé, a existencial e a noética, derivam de um homem concreto, de uma situação de experiência pessoal vivida. O primeiro é do tipo "fé-confiança" em alguém. O segundo é a "fé-crença" naquilo que se põe como verdadeiro, por exemplo, as assertivas dogmáticas. Nas palavras de Buber:

A relação de confiança repousa sobre uma situação de contato, um contato da totalidade de meu ser com aquele no qual confio, a relação de reconhecimento repousa sobre um ato de aceitação, uma aceitação pela totalidade de minha pessoa daquilo que eu reconheço como verdadeiro. (BUBER, 2007, p. 30).

Para Buber, a aceitação da verdade por mim reconhecida é um meio que me permite atingir o contato com aquele do qual é o testemunho. "Entretanto, argumenta Buber, num caso, o que é primeiro é o contato existente, e no outro é a aceitação como fato consumado". (BUBER, 2007, p. 30). O autor explica que a pessoa que confia não tem conhecimento do início da confiança no tempo; ela simplesmente o identifica como o início do contato. Por outro lado, o crente que reconhece e se relaciona com aquilo que reconhece como verdadeiro não o aceita como se fosse uma coisa nova, a qual acaba de surgir, mas como algo eterno que acaba de se tornar atual. Na verdade, o decisivo é, de um lado, o estado e, de outro lado, o ato (BUBER, 2007 p. 30).

Passando para o sentido religioso, a fé, enfatiza Buber, é uma dessas duas maneiras de crer na esfera do incondicionado; é uma relação com aquilo que é incondicionado. As duas maneiras de crer se defrontam mutuamente. Com efeito, Buber estabelece uma distinção entre elas: em uma, o homem "se encontra" na 
relação de fé; na outra, ele "se converte" a essa relação. Além disso, o homem que é habitado por essa relação é membro de uma comunidade cuja aliança com o Incondicionado o abraça e o determina. Por outro lado, o homem que se converte a essa relação é, antes de tudo, um indivíduo que se tornou tal, e a comunidade nasce como sociedade de indivíduos conversos (BUBER, 2007, p.30). Buber rejeita e hipótese segundo a qual, para simplificar as coisas, se afirma que ambos os tipos estão em oposição. Ao contrário, deve-se levar em consideração que a imbricação essencial entre ambos é relevante para a história da fé.

Da mesma forma que a Emunah requer "retorno"8, a Pistis requer metanoia, vale dizer, "conversão”. No primeiro modo, a situação na qual o homem se encontra é de proximidade, de “contato". Assim afirma Buber:

mas persiste em tudo o que foi desenvolvido a partir daí uma distância derradeira indefectível. Em contrapartida, o ato pelo qual o homem reconhece pressupõe a distância entre um sujeito e seu objeto; porém aquilo que daí emana, a relação com o ser visado no fato reconhecido, pode desenvolver-se, tornando-se muito íntimo e caminhar mesmo até o sentimento de união. (BUBER, 2007, p.30).

Judaísmo e cristianismo representam esses dois tipos de fé, especialmente em seus primórdios. A primeira é expressa pelo termo hebreu Emunah. O segundo tipo é expresso pelo termo grego Pistis, especialmente quando usado pelo apóstolo Paulo. Emil Brunner, teólogo cristão, analisando a obra de Buber, indaga:

O que é, então, precisamente a antítese de "dois tipos de fé”, de um lado, a fé judaica do Antigo Testamento que é igualmente a fé de Jesus e de seus ensinamentos, e, de outro lado, a fé paulina-joanina que constituiu a cristandade e na qual ela repousa como em seu fundamento? (BRUNNER, 1967, p. 313).

Assim, Buber ilustra a primeira maneira de crer com o que ele denomina o período primitivo do povo crente, Israel, uma comunidade de fé nascida como

\footnotetext{
${ }^{8}$ Essa é a tradução do termo hebraico t'shuvah. No texto bíblico, o termo tem um sentido distinto do que aquele comum na literatura e na liturgia. Segundo a doutrina hebraica, o homem pode a qualquer tempo "retornar" e ser aceito por Deus, sem mediação alguma. Essa noção de retorno se encontra no coração do judaísmo.
} 
povo, povo nascido como comunidade de fé (BUBER, 2007, p.31). Para Buber, Israel proveio da reunificação de povos e famílias, perfazendo uma aliança com Deus, como o Deus da aliança. Assim, argumenta o autor:

Se, como o presumo se puder seguir nesse ponto os relatos bíblicos, essa fé em Deus nasceu por ocasião das peregrinações que forjavam tribos e forjavam um povo, e era vivida como uma experiência conduzida por Deus. [...]. A fé desse povo era uma confiança perseverante em Deus que o guia e que faz aliança, perseverança confiante em seu contato. (BUBER, 2007, p. 31).

O indivíduo se encontra, segundo Buber, na memória objetiva que as gerações têm dessa conduta e dessa aliança. "Sua fé é confiança perseverante no Deus que o guia e faz aliança, perseverança confiante em seu contato.” (BUBER, 2007, p.31). Essa maneira de crer só veio a ser modificada tardiamente, na diáspora tomada pelo helenismo e nas tentativas missionárias visando à adaptação às pessoas. Essa mudança não veio a ser efetiva na natureza da fé. A essa altura, surgiu a cristandade, cujo início está na diáspora e na missão (BUBER, 2007, p.31). A missão, mais do que difusão, é um impulso vital de comunhão, permitindo aos crentes comporem uma comunidade.

De acordo com Buber, as duas maneiras de crer se diferenciam pela sua origem. A fé hebraica surge em um povo que vive uma "experiência de fé”. Assevera Buber: "O apelo de Jesus a entrar, pelo arrependimento, no reino de Deus 'que está próximo' tornou-se obra de conversão: “conversão à fé'.” (BUBER, 2007, p.31). O povo hebreu e, no seu seio, o indivíduo "guardam na memória” o mistério de sua eleição por Javé e da sua aliança. Essa memória transmitida através de gerações, é uma memória quase "corpórea” (leibhaft) (2007, p. 31). Missão “[...] não significa somente difusão, é um sopro vital da comunhão enquanto constitui um "novo povo de Deus".

O homem, ávido de redenção, em momentos de desespero, vê sendo-lhe oferecida a redenção, contanto que creia que ela se realizou e que se realizou de tal modo. Nesse caso, não se trata de perseverar, mas, ao contrário, de fazer um retorno. (Umkher). (BUBER, 2007, p.31). 
A fé hebraica é uma força através do tempo e a fé cristã é um movimento que transpõe o espaço. Mesmo que não o afirme de maneira explícita, a meu ver, é plausível imaginar que o autor elabora uma fenomenologia da crença, assim como em Eu e Tu havia esboçado, de certo modo, uma fenomenologia das atitudes do homem no mundo.

Uma das questões que se apresenta é: quem é o sujeito dessa intencionalidade? Quem é o crente? Como expressa sua fé? Entende-se, no decorrer da argumentação de Buber, que o crente assenta sua experiência religiosa na relação direta com Deus. O autor, nos três primeiros capítulos, por meio de uma correlação de textos da Escritura hebraica e do Novo Testamento, em especial os Evangelhos e as cartas de Paulo, explicita sua posição concernente aos dois tipos de fé. É o que exponho a seguir.

\subsection{0 crente: Marcos e Isaías}

No capítulo primeiro, Buber retoma um episódio narrado por Marcos (9. 1419). O texto relata que um pai traz seu filho possuído pelo demônio, primeiro aos discípulos e, como “eles não podem curá-lo”, invoca o próprio Jesus, dizendo: “Se tu podes alguma coisa tenha piedade de nós e nos ajude”. E Jesus respondeu "Se tu podes, crer, tudo é possível para aquele que crê.” E o pai retruca: "Eu creio, ajudame na minha incredulidade."

Buber concentra a reflexão nas duas "palavras-motivo", crer e poder, que o relato evidencia. E continua: "[...] ambos repetidos em duas tomadas, expressamente a fim de inculcar no leitor que ele recebe um ensinamento decisivo sobre a relação existente para o homem essencialmente em situação de 'crer', ou essencialmente em situação de 'poder'." (BUBER, 2007 p. 37), demonstra como a fé de Jesus é Emunah pura em oposição à dos discípulos. Ainda segundo o relato, Jesus tomou-o pela mão, levantou-o e o moço se colocou em pé. Em seguida, Jesus entrou numa casa e os discípulos, de modo reservado, perguntaram-lhe por que 
não puderam curá-lo. E Jesus respondeu: "Essa espécie de demônios não se pode expulsar senão pela oração (Mc. 9, 14-29). O relato enfatiza que Jesus pode curar porque crê e sua fé é emunah, ao contrário dos discípulos, os quais não podem curar, porque não creem. Assevera Buber:

O problema da relação entre fé e "poder" aparece aqui diretamente na questão dos discípulos, perguntando por que eles não puderam expulsar os demônios, e na resposta de Jesus, que começa trazendo um esclarecimento: "é por causa de sua incredulidade"; é, portanto, aos discípulos que é imputada essa não-fé, oposta por natureza à fé [...]. (BUBER, 2007, p. 39).

Na sequência, Buber volta a considerar a relação entre poder e crer. "Tudo é possível àquele que crê.” Ele alude a passagens do Antigo Testamento, a uma passagem em Marcos (Mc. 10, 27) e em Mateus (Mt. 19, 26), conforme as quais a Deus tudo é possível. O crente, para Buber, adentra no domínio de Deus, onde existe a "onipossibilidade" e a onipotência. Esta é atributo exclusivo de Deus. Argumenta Buber:

As fórmulas "possível a Deus" e "possível ao homem" não se recobrem. “Tudo é possível junto a Deus" não significa - e os discípulos que o escutam o sabem - que Deus é capaz de tudo [...] mas que ali, junto a Deus, na sua esfera, na sua proximidade e em comunhão com Ele9, nada é impossível, e, portanto tudo o que é, por outro lado, impossível, se torna aqui possível. (BUBER, 2007, p.40).

A noção de crente modelada na leitura de Buber não foi germinada em terra helênica. Tudo o que, segundo o autor, na literatura grega pré-cristã e nos trágicos lhe parece mais próximo, remete sempre a um estado de alma e "[...] não uma realidade relacional transcendendo o mundo da pessoa." (BUBER, 2007, p.40). No entender de Buber, ela se encontra unicamente no Antigo Testamento. Ele se baseia em um verso de Isaías $(28,16)$, no qual Deus anuncia que irá colocar em Sião “[...] uma pedra, uma pedra de granito, pedra angular e preciosa, uma pedra de alicerce bem firmada: aquele que nela puser sua confiança (grifo meu) não será abalado".

\footnotetext{
${ }^{9}$ Buber cita passagens de Mt.6, 1; Jn 8,38; Jn 17, 5.
} 
Aquele que crê, ademais, não desejará precipitar a vontade de Deus; “[...] crer, em todo o Antigo Testamento, significa caminhar na vontade de Deus, e também em relação à realização temporal de sua vontade: o crente opera no ritmo de Deus.” (BUBER, 2007, p.41). Buber apresenta não só a diferença entre o Antigo e o Novo Testamento, mas entende que há semelhança entre noções de crente passivo e ativo.

Assim se encontram reunidos o "crente" passivo de Israel, e o crente "ativo" do Evangelho. Este age, porque a hora divina lhe ordena agir; o fato, para o jovem enfermo, de encontrá-lo em seu caminho, indica que a cura é uma ordem divina; também ele não pode agir senão no ritmo de Deus. (BUBER, 2007, p. 41).

De acordo com Buber, o poder de Deus envolve ambos os crentes, mesmo se, às vezes, o homem não esteja consciente. $\mathrm{O}$ crente impotente, o enfermo do Evangelho, torna-se potente, porque Deus assim o faz. O autor nota, ainda, uma congruência entre as passagens citadas, de Marcos e de Isaías, pela proximidade linguística, ao se empregar o termo “crente" como particípio substantivado, por assim dizer, de modo absoluto. Buber sustenta que o fato de não se acrescentar em “quem” o crente crê tem sentido vigoroso e é fundado solidamente. Não se trata, salienta o autor, do uso de uma manobra de abreviação, a partir da omissão simples de um "em Deus", considerando-se que isso é, por si, evidente. Aliás, prossegue ele, isso não aparece nem nos Sinóticos. Se se acrescentasse "em Deus", seria alterado o verdadeiro caráter do conceito ou, no mínimo, isso o debilitaria. Essa construção absoluta quer indicar, em ambos os casos, o caráter absoluto do que é justamente visado (BUBER, 2007, p.41). Porém, não se deve daí concluir que se esteja diante uma noção de “fé em geral”, desconhecida, aliás, tanto no Antigo como no Novo Testamento. Significa, ao contrário, que todo acréscimo que serve, comumente, para caracterizar um estado de alma, “[...] seria, por natureza, uma perda da plenitude e da força daquilo que é visado, isto é, dessa realidade relacional que transcende, na verdade, o universo da pessoa.” (BUBER, 2007, p. 41). 


\subsection{Crer e confiar: Mateus e Isaías}

Buber, no segundo capítulo da obra, retoma a passagem do Evangelho de Mateus, onde relata uma predicação de Jesus na Galiléia, igual àquela pela qual João Batista havia inaugurado os batismos no deserto: “Convertei-vos, pois o Reino dos céus está próximo.” Por outro lado, observa Buber, pelo relato encontrado em Marcos, que não se refere a João Batista, Jesus se expressa assim: "O tempo determinado foi cumprido, o Reino de Deus se realizou. Convertei-vos e crede na Boa Nova.” Buber observa que o último verbo corresponde à tradução grega de um verso do salmo 106 (105), 12, e pode ser traduzido como no grego “Tende confiança na Boa Nova.” (BUBER, 2007, p.44). E expõe como o homem deve ter confiança no poder de Deus sobre o mundo que se aproxima. O homem deve prestar fé no teor central da mensagem. Pondera Buber:

Não é mais à sua palavra que o orador convida seus ouvintes a dar a sua fé: trata-se do teor central da própria mensagem. [...] para poder dela se acessar, afaste-se, ó você, homem da escuta, de seus erros, toma o caminho de Deus, entre em comunhão com Ele no qual reinam todas as possibilidades, e abandone-se ao seu poder. (BUBER, 2007, p.43).

Crer significa ter confiança. Porém, isso não significa um simples estado de alma que é exigido da integração da conversão. E mais, essa conversão não basta para realizar a realidade humana. Tem necessidade da Pistis, mais justamente, da Emunah. A Teshuva, reduzida inevitavelmente pelo tradutor grego em metanoia, ou simples mudança de mentalidade, e Emunah, confiança, “[...] ela também, inevitavelmente transformada por ele em Pistis, em reconhecimento 'crente' de verdades, ambas se atraem e se condicionam reciprocamente." (BUBER, 2007, p.45). Interessante o esclarecimento de Buber no que concerne o termo Teshuva ou o retorno da pessoa em sua totalidade. Afirma ele: "Deve-se notar que o Antigo Testamento não conhece o nome nesse sentido, mas somente o verbo (retornar); retornar a Deus é ainda compreendido exclusivamente como algo de concreto e de 
atual” (BUBER, 2007, p. 44, nota 2). David Flusser ${ }^{10}$ observa, no posfácio da tradução inglesa da obra de Buber: "Não há no hebraico bíblico um nome com esse sentido. No texto bíblico, o termo Teshuva significa somente "[...] 'ser trazido de volta' e nada mais.” (FLUSSER, 2003, p. 185). Flusser sublinha ainda que existe um verbo na Escritura hebraica para "ter fé" (Glauben), mas o termo Emunah, construído com o mesmo tronco, não significa, na verdade, a fé (der Glaube). E nota, além disso, que Emunah é construído de acordo com a mesma estrutura gramatical que Teshuva, o retorno (FLUSSER, 2003, p.185). Esse autor assevera que é tese admitida comumente que a fé, em sua dimensão religiosa, é uma invenção judaica, e que, por outro lado, o politeísmo pagão dificilmente poderia oferecer algum espaço para o conceito de “crer em Deus” (FLUSSER, 2003, p. 185).

Descobrimos, assim, nessa relação com Deus, os três princípios da fé humana, no seio da mensagem: realização do reino de Deus, conversão efetiva a Deus e a realização de fé com Ele. "O apelo a voltar-se 'a Deus' ou 'até Deus'” observa Buber, “[...] é a palavra primordial dos profetas de Israel.” (BUBER, 2007, p.45). O autor escolhe alguns trechos do Antigo testamento para entender, de modo mais denso, o sentido originário a ser atribuído à fé. “O imperativo 'crede' ('tende confiança') encontra-se tardiamente no Antigo Testamento, em um relato do livro das Crônicas (2 Ch 20,20)"11. (BUBER, 2007, p.46). E, em uma palavra de Isaías a Achab de Judá, percebe-se a articulação entre "ter confiança” e "estar seguro". "Se não o credes, não vos mantereis firmes.” (Is 7,9). São duas formas verbais, ressalta Buber (no texto de Isaías), que remetem a um sentido original: estar firme, estar seguro. Na sua interpretação da palavra do profeta, Buber argumenta, fazendo referência à situação existencial:

Traduzindo em nossa língua conceitual, o profeta fala assim: somente se você permanecer firme na sua relação existencial e essencial, você ficará firme naquilo que é essencial. Uma existência humana não é

\footnotetext{
${ }^{10}$ David Flusser (1917-2000) foi um eminente filólogo austríaco, radicado em Israel, professor na Universidade Hebraica de Jerusalém, especialista na questão das origens da cristandade e o judaísmo. Suas principais obras são: Judaism and the Origins of Christianity (1988) e Jesus (1998). Escreveu um posfácio para a tradução inglesa da obra de Buber Two types of Faith (2003).

11 "Quando partiram, Josafá, de pé, exclamou: Ouvi-me, Judá e habitantes de Jerusalém! Crede em Jahweh vosso Deus e estareis seguros; crede em seus profetas e sereis bem-sucedidos."
} 
verdadeiramente estável em seus fundamentos, a não ser que essa estabilidade provenha da verdadeira estabilidade originada na relação fundamental que esse homem entretém com o Poder criador de seu ser. (BUBER, 2007, p.46).

Buber observa, ademais, que o caráter existencial da Emunah não está entendido de modo suficiente na tradução "fé", uma vez que o verbo significa muitas vezes crer, crer em alguém, crer numa coisa; enfatiza o autor que o conceito engloba dois aspectos de uma reciprocidade na "estabilidade", no "estar firme": o aspecto ativo que é a "fidelidade", e o aspecto passivo que é a "confiança". E conclui sua análise, defendendo que a palavra de Isaías e a palavra de Jesus, tanto uma como outra, não exigem uma fé "em Deus", pois, para seus ouvintes, isso é algo inato e evidente. Exigiam, na verdade, uma fé que se realiza na totalidade da vida, especificamente, quando, no âmago de uma catástrofe, brilha a promessa, vale dizer, a aproximação do Reino de Deus (BUBER, 2007, p. 47). Quer na confiança, quer na fidelidade, a atitude espiritual deve tornar-se uma atitude existencial, uma atitude de vida. "Ambas, afirma Buber, fidelidade e confiança, existem no espaço relacional entre dois seres. Somente na realidade relacional vivida na sua plenitude se pode ser fiel e confiante." (BUBER, 2007, p.47).

A única diferença entre Isaías e Jesus, acrescenta Buber, é que Isaías falava olhando para o Reino de Deus como para um futuro, ainda indeterminado. E Jesus voltava seu olhar para o presente. As mensagens de Isaías, no relato que ele faz do início de sua atividade, estão apresentadas em primeira pessoa, em três momentos que se sucedem (Is. 6-8): o momento em que ele vê o Rei (Is. 6, 5); o momento em que ele dá a seu filho o nome de Sear-Jasub ("um resto que voltará"); e o momento em que ele convida o vigário infiel de Deus a ter confiança (Is. 7, 9). Em Jesus, esses momentos são fundidos "[...] na palavra fundamental de sua predicação" na Galileia (BUBER, 2007, p. 47). Buber conclui, pois, propondo uma síntese entre o pensamento de Isaías e o de Jesus, afirmando que entre ambos não se trata de ver uma "fé em Deus", mas uma atitude que se realiza na plenitude da vida. 


\subsection{A indagação de Jesus: Marcos e João}

No terceiro capítulo da obra, Buber dirige o foco da análise a um diálogo entre Jesus e seus discípulos, narrado por Marcos. Jesus desejava saber o que seus discípulos pensavam dele.

Jesus partiu com seus discípulos para os povoados de Cesaréia de Felipe e, no caminho, lhes perguntou: "Quem dizem os homens que eu sou?" Eles responderam: "João Batista"; outros, "Elias"; outros, ainda, "um dos profetas." "E vós, perguntou ele, quem dizeis que eu sou?” Pedro respondeu: "Tu és o Cristo." Então, proibiu-os severamente de falar a alguém a seu respeito. (Mc. 8, 27 s.).

Buber interpreta da seguinte maneira. Ele cita a concepção de Bultmann ${ }^{12}$, que vê nessa passagem uma "lenda de fé” pela qual a comunidade põe na boca do apóstolo sua própria confissão de fé. Em acréscimo, a questão da opinião dos apóstolos não poderia ser entendida como uma questão socrática. Na verdade, não poderia ser entendida como uma verdadeira indagação, pois Jesus deveria estar tão bem informado quanto seus discípulos. Buber, entretanto, descarta tal interpretação, mas declara: “[...] mas penso que me é plenamente possível pensá-la como uma questão colocada com extrema gravidade.” (BUBER, 2007, p. 49). É plausível supor, argumenta Buber, que a indagação de Jesus é a de alguém “[...] que não considera a certeza de um homem sobre sua própria pessoa como uma linha sem falha, mesmo que fosse a certeza mais nobre do homem mais extraordinário.” (BUBER, 2007, p. 49). Em outras palavras, um homem santo, o que tem fé, também tem dúvidas, passa por crises e, mesmo assim, é capaz de dialogar para se conscientizar da sua fé. Buber acena, sem amplas considerações, à questão da “consciência messiânica” de Jesus. Destaca ele:

Um mestre, cujo ensinamento depende inteiramente daquilo que é assumido por sua pessoa e, portanto, de sua natureza, pressentindo que, para seu destino e o destino de sua obra, se encontra no cruzamento dos caminhos, esse mestre foi tomado pela incerteza e se indaga "quem" ele próprio é. (BUBER, 2007, p. 50).

${ }^{12}$ Die Geschichte der synoptischen Tradition. 2. ed. 1931, p.276. 
Buber prossegue em sua análise, considerando que um mestre que não tem mais um mestre e, pelo visto não tem mais um amigo informado sobre sua pessoa, a quem mais poderia indagar, se não aos seus discípulos, pois, se há alguém capaz de dar alguma resposta, estará no meio deles. E conclui: “[...] é no contato único que estabelece tal relação mestre-discípulo que eles fizeram a experiência na qual pode ser buscada a resposta." (BUBER, 2007, p. 50). Buber, na sequência do texto, faz a comparação com um excerto do Evangelho de João, indicando a diferença, entre ambos, sobre a concepção da fé. Nos Evangelhos sinóticos, observa Buber, Pedro sempre responde por uma simples frase: Tu és o Cristo" ou "o Filho de Deus vivo", "o Ungido de Deus". Em João, tanto a pergunta quanto a resposta estão ausentes. O Jesus de João, destaca Buber, por pertencer a uma esfera espiritual e não humana, não está sujeito a momentos de dúvida. Ao contrário, Pedro, em outro contexto, responde de outra maneira. Quando Jesus diz a seus discípulos: "Não quereis também vós partir?", Simão Pedro respondeu-lhe: “Senhor, a quem iremos? Tens palavras de vida eterna e nós cremos e reconhecemos que és o Santo de Deus." (Jo 6, 67). Buber sugere outra versão para "nós cremos e reconhecemos"; na verdade, seria "adquirimos a fé e o conhecimento". Eles creem e conhecem que Jesus é o Santo de Deus. Quanto à questão "quem", acerca da qual os discípulos dão sua opinião, Pedro, no primeiro caso, emite uma declaração a respeito da natureza de Jesus e, no segundo, ele confessa sua fé e seu conhecimento numa frase enunciativa. Observa Buber: "O que era expresso diretamente nos sinóticos, aqui se tornou uma declaração sobre os discípulos.” (BUBER, 2007, p. 51). Aquilo que, na perspectiva de Marcos, se referia à natureza de Jesus como Cristo, na de João, a intenção é dar conta da fé dos discípulos, esclarecendo como eles creram e conheceram o Santo de Deus, consagrado como Messias. Essa fé é obra de Deus ${ }^{13}$. Buber observa ainda que há como que uma linha de separação traçada de sorte a colocar, no que concerne ao modo de crer, Israel e a comunidade primitiva, tal como se percebe nos sinóticos, de um lado, e o cristianismo helenístico de outro. $\mathrm{O}$ que diz Pedro no Evangelho de João, ao sublinhar sua fé e seu conhecimento, é a

\footnotetext{
${ }^{13}$ Disseram-Ihe, então: "Que faremos para trabalhar na obra de Deus?". Respondeu-lhes Jesus: "A obra de Deus é que creiais naquele que Ele enviou". (Jo. 6, 29).
} 
manifestação de uma teologia refinada, todavia, desaparece a situação concreta e simples do diálogo que se encontra em Marcos.

Quanto a esse diálogo com os discípulos, se for levado em conta nos sinóticos e em João como duas etapas de um mesmo caminho, argumenta Buber, o que é um ganho e o que é uma perda? Pode-se tomar como ganho, em João, “a mais sublime de todas as teologias". O perdido foi a simplicidade da vivência dialógica que “[...] se encontra na profundeza do instante real, a dialógica do homem bíblico primitivo, ao lado do qual convém colocar Jesus da autêntica tradição, mas não mais aquele de uma teologia.” (BUBER, 2007, p. 52).

O autor deixa clara sua posição quando observa que, diante do que é relatado no Novo Testamento, aquilo que é “cristão” diverge daquilo que é “judeu”. E apresenta uma crítica ao judaísmo medieval, o qual inflectiu sua maneira de crer num sentido em que, dogmaticamente, "se crê que" a ponto de, na Idade Média, inserir seu Credo numa forma tão estreita quanto qualquer Igreja cristã. ${ }^{14}$

Em suma, Buber afirma a existência de dois tipos de fé: “[...] na declaração: 'É verdade que o Deus do mundo é nosso Deus', a diferença entre 'é verdade que' e 'Nós cremos e conhecemos' não é aquela entre duas expressões de fé, mas a de dois tipos de fé de natureza diferente." (BUBER, 2007, p. 52). No primeiro caso, a fé é a condição na qual alguém "se encontra" - Emunah; no segundo, a fé é um acontecimento que ocorreu a uma pessoa, ou um ato realizado - Pistis. O povo de Israel não está ligado a uma fé que tem o formato de uma confissão de fé. O Deus de Israel é o Deus fiel, a cuja palavra o crente pode abandonar-se plenamente.

\section{Considerações finais}

Para o povo de Israel, a marcha para Canaã representou sua entrada na história. Essa experiência de ter sido guiado em meio a perigos no deserto, fato único na história, é o nascimento da Emunah. A Emunah é a confiança

${ }^{14} \mathrm{O}$ autor se refere, sem dúvida, a Maimônides. 
perseverante do homem em sua relação com o guia invisível, que se revela escondido, mas que se manifesta. O indivíduo tem Emunah pessoal incorporada àquela do povo. Historicamente, no processo de individuação, a incorporação muda na forma, mas não em sua essência.

A Pistis cristã surgiu fora de experiências históricas dos povos, mas nas almas de indivíduos levados pela crença de que um homem, crucificado em Jerusalém, era seu Redentor. Essa fé, apesar de sua “irracionalidade”, na expressão de Buber, deve ser qualificada de lógica ou poética: “aceitar-como-verdadeiro” e "reconhecer-como-verdadeiro" aquilo que uma proposição proclama sobre o objeto da fé (BUBER, 2007, p. 164). O ato pelo qual se toma conhecimento das coisas tais como são, para além de qualquer conceito usual, é eminentemente grego na sua origem. É um ato de uma pessoa que se separava da comunidade de seu povo. Jesus se dirigia, sem dúvida, ao indivíduo e, quando falava a uma multidão, falava aos indivíduos. Mateus $(15,24)$ narra quando Jesus fala das "ovelhas perdidas da casa de Israel”. Ele continua a vê-las integradas à “casa”. Depois de Jesus, não se ouve mais falar coisas parecidas.

Assim, argumenta Buber:

Doravante não é necessário debater a fé como princípio de reconhecimento e de aceitação, no sentido de reconhecer, de origem grega. Com efeito, somente o pensamento grego, que chegou a apreender um ato de reconhecimento de uma verdade, a tornou possível. (BUBER, 2007, p.32).

Com a distinção que estabelece entre Emunah e Pistis, Buber não pretende propor alguma definição grega pagã de fé religiosa. David Flusser, sobre a questão de uma concepção de fé religiosa na Grécia pagã, ressalta: “Na verdade, talvez não tivesse sido essa a intenção de Buber. Aparentemente ele só quisesse afirmar que o tipo de fé cristã provinha do universo grego de pensamento.” (FLUSSER apud BUBER, 2003, p. 179). 
Buber observa que, quando Paulo fala de judeus e gregos, jamais o faz a partir de sua realidade nacional. Não se trata, para ele, senão da nova comunidade que, por natureza, não é uma nação. A concepção de “povo santo” empalideceu, salienta Buber, não penetra na consciência da cristandade. A Igreja tomará seu lugar e será doravante o "único povo de Deus”. “Assim, aqueles que crêem no Cristo tinham a cada dia uma existência dividida, isto é, como indivíduos que vivem na esfera da pessoa, e como participantes da vida pública de seus povos.” (BUBER, 2007, p. 165).

Pode-se apreender que as análises de Buber opõem a fé messiânica “de” Jesus e a fé dogmática "em Jesus". Ele entende tal oposição em termos de um contraste radical entre a fé na situação concreta do homem bíblico, a saber, Jesus em um momento histórico, e a cristologia de Paulo, a qual orienta a si mesmo à transcendência eterna do Cristo ressuscitado.

Buber distingue entre essas duas formas de fé “de" e fé “em” Jesus, a fim de reconstruir uma história complexa de separações, alienações e oposições, conduzindo a fé vivida original, isto é, o diálogo homem com Deus, "fé-confiança" de Jesus no Reino de Deus para um conhecimento objetivo, submetendo a si mesmo a poderes existentes nesse mundo, na esperança de redenção por meio do Cristo celestial.

Para o autor, a fé cristã exige vários mediadores: o Cristo, que se tornou objeto de fé, e as proposições de fé. Segundo ele, a concepção de fé do cristianismo foi vítima do intelectualismo helênico e, por isso, perdeu a espontaneidade do encontro do homem, na totalidade de seu ser, com Deus, própria da emunah. A posição se mostra bem clara, no decorrer de toda a obra: ele faz uma clara distinção entre emunah e pistis.

De fato, Buber censura os seguidores de Jesus, em especial Paulo e João, pelo fenômeno do cristianismo. Com eles, teria sido dado o início da deificação de Jesus. Lemos, em João 3:13:” Ninguém subiu ao céu, a não ser aquele que desceu 
do céu, o Filho do homem.” Buber argumenta: “[...] daqui até a deificação, basta tomar somente um degrau a mais.” E cita Paulo, na carta aos Coríntios: “E, se Cristo não ressuscitou, vazia é nossa pregação, vazia é também a vossa fé” (Cor. 15:14).

Observe-se que essa obra, na qual o autor considera o judaísmo e o cristianismo em sua respectiva natureza em confronto mútuo, não conduz ao velamento da questão da identidade de Jesus. Sua cuidadosa exegese dos Evangelhos propicia-lhe esclarecer a fé - emunah - de Jesus. Isso lhe permitiu aprofundar sua pesquisa sobre a realidade do judaísmo. Por outro lado, para Buber, os cristãos só se relacionam com Jesus por intermédio da teologia de Paulo e de João. Enquanto os judeus têm acesso à experiência de fé de Jesus, os cristãos se veem diante de uma interpretação teológica. Em outro contexto ${ }^{15}$, em um evento do qual participavam indivíduos de diversas proveniências e confissões, Buber, em reação à observação de um participante, afirmou:

Não sei mais por que vias cheguei a falar, dentro deste contexto, de Jesus e dizer que nós, judeus, o conhecíamos do interior, nos impulsos e nas emoções do seu ser judeu, numa forma que permanece inacessível aos povos que estão sob sua égide. "De uma forma que vos parece inacessível”, assim falei diretamente ao antigo padre. (BUBER, 1982, p. 38).

Buber tenta estabelecer, por meio de uma cuidadosa exegese da Bíblia hebraica, dos Evangelhos e dos textos de Paulo, a identidade de Jesus, ao tratar da fé de Jesus Nazareno, traçando um perfil fidedigno de uma experiência religiosa que revela o âmago da personalidade histórica de Jesus, cuja religiosidade representa o ápice da fé dos profetas. Eugen Biser ${ }^{16}$, em sua obra, emprega a expressão “recondução de Jesus” (Zurückholung Jesu) (BISER, 1988, p. 109-116), isto é, recuperar a "judaicidade" de Jesus. O profetismo constitui, por assim dizer, a

\footnotetext{
${ }_{15}$ Buber refere-se, em seu ensaio "Diálogo" (Zwieschprache), publicado na obra O princípio dialógico (BUBER, 1962. Das dialogische Prinzip), a uma reunião, ocorrida na Páscoa de 1914, de indivíduos pertencentes a diversos povos europeus, com a finalidade de constituírem uma autoridade supranacional.

${ }^{16}$ Eugen Biser (1918-2014), filósofo e teólogo católico alemão. Especialista em Teologia Fundamental, foi professor nas Universidades de Würzburg, de Marburg e de Bochum. Dentre sua vasta obra, publicou o livro Buber für Christen. Eine Herausforderung. (BISER, 1988)
} 
chave hermenêutica para compreensão do homem Jesus. Essa busca do "ser judeu" de Jesus é acompanhada de uma recusa da "distorção" da sua mensagem pela Igreja. De acordo com Buber, Paulo foi o responsável, quando esteve insistindo fortemente para crer no Cristo. E Paulo fazia exatamente o que Jesus não fez, tanto quanto se pode saber por meio dos sinóticos.

Essa obra de Buber nos oferece a visão de um Jesus judeu que ensinou a cumprir a vontade de Deus e não anunciou uma nova fé; um judeu obediente à vontade de Deus contida na Lei, cujo intenso objetivo era implantar na nação judaica a ideia do Reino de Deus.

Concluo com um pensamento expresso por Buber com convicção, sem dúvida esperando fosse compartilhado. Assim enfatiza ele, no final de seu livro:

\begin{abstract}
Além disso, podemos pressentir que, mesmo no presente, há um caminho que conduz do paulinismo rígido a uma Pistis de configuração diferente, mais próximo da Emunah. A fé do judaísmo e a fé do cristianismo são, à sua maneira, essencialmente diferentes, cada uma segundo seu enraizamento humano e, provavelmente, permanecerão diferentes por natureza, até que a raça humana tenha sido recolhida dos exílios das "religiões", no Reino de Deus. Porém, um Israel esforçando-se em renovar sua fé pelo renascimento da pessoa e um cristianismo esforçando-se em renovar sua fé no renascimento dos povos teriam coisas não ditas a se dizerem, e um auxílio mútuo a se ofertar, dificilmente imaginável hoje. (BUBER, 2007, p. 57).
\end{abstract}

Tal afirmação revela, de forma clara, a dedicação alimentada durante muitos anos pelo apreço que Buber demonstrava ao Novo Testamento, fato destacado por muitos intérpretes judeus e cristãos, e pelo sentimento de grande respeito à pessoa de Jesus, como ele próprio mencionou, no início da obra. Tais situações, sem dúvida, vieram fortalecer seu projeto essencial, ao qual dedicou sua vida de restauração e revigoramento espiritual do ser judeu na sua integridade. Por isso, seu desejo de que Israel e o Cristianismo "[...] teriam coisas não ditas a se dizerem, e um auxílio mútuo a se ofertar”. 


\section{REFERÊNCIAS}

BALTHAZAR, Hans Urs. Martin Buber and Christianity. In: SCHILPP, Paul Arthur; FRIEDMAN, Maurice (Ed.). The philosophy of Martin Buber. La Salle (Illinois): Open Court, 1967. p. 341-359.

BEN-CHORIN, Schalom. Zwiesprache mit Martin Buber. München: List, 1966.

BIBLIA DE JERUSALÉM. São Paulo:Paulus . 1a.edição 2001. 9a. Reinterpretação 2013.

BISER, Eugen. Buber für Christen. Eine Herausforderung. Freiburg in Brisgau: Herder, 1988.

BRUNNER ,Emil. Judaism and Christianity. In: SCHILPP, Paul Arthur; FRIEDMANN, Maurice (Ed.). The philosophy of Martin Buber. La Salle (Illinois): Open Court, 1967.

BUBER, 1962. Das dialogische Prinzip. Heidelberg: Schneider, 1962.

BUBER, Martin. Do diálogo e do dialógico. São Paulo: Perspectiva, 1982.

BUBER, Martin. Der Glaube der Propheten. Zu“ rich: Manesse Verlag, 1950.

BUBER, Martin. Deux types de foi, foi juive et foi chrétienne. Tradução de Bernard Delattre. Paris: Cerf, 2007.

BUBER, Martin. Eu e Tu ( Ich und Du). Tradução de Newton Aquiles von Zuben. São Paulo: Centauro, 4${ }^{\mathrm{a}}$. Reimpressão 2012.

BUBER, Martin. Moses. New York: Conference on Jewish relations, 1945.

BUBER, Martin. Replies to my Critics. In: SCHILPP, Paul Arthur; FRIEDMANN, Maurice (Ed.). The philosophy of Martin Buber. La Salle (Illinois): Open Court, 1967.

BUBER, Martin. Zur Geschichte des Individuationsproblem: Nicholas von Cuse und Jakob Böhme. 1903. Disponível em: < https://www.academia.edu/4082594/Martin_Buber__Zur_Geschichte_des_Individuationsproblems._Nicolaus_von_Cues_und_Jakob_B\%C3 \%B6hme_Niccol\%C3\%B2_Cusano_e_Jakob_B\%C3\%B6hme_._Per_la_storia_del_probl ema_dellindividuazione_.A_cura_di_F._Ferrari_2013_>. Acesso em: 21 jan. 2016.

BUBER, Martin. Zwei Glaubesweisen. Zürich: Manesse, 1950.

FLUSSER, David et al. Buber Two types of Faith. Syracuse, NY: Syracuse University Press, 2003. 
FLUSSER, David. Afterword [na tradução inglesa]. In: BUBER, Martin. Two types of faith. Syracuse: Syracuse University Press, 2003. p.175-235.

FLUSSER, David. Jesus. New York: Herder and Herder, 1968.

FLUSSER, David. Judaism and the Origins of Christianity. Jerusalem: Magnes Press Hebrew University, 1988.

HORWITZ, Rivka. Buber's Way to "I and Thou". An historical analysis and the first publication of Martin Buber's “Religion als Gegenwart”. Heidelberg: L. Schneider, 1978.

SCHILPP, Paul Arthur; FRIEDMANN, Maurice. The philosophy of Martin Buber. La Salle (Illinois): Open Court, 1967. 